2

4

6

8

\title{
Densities and population sizes of raptors in Uganda's conservation areas
}

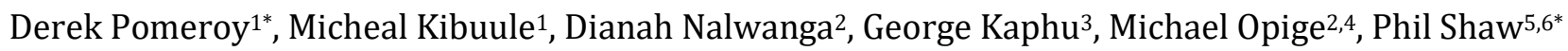

1 Department of Zoology, Makerere University, PO Box 7298 Kampala, Uganda

2 NatureUganda, PO Box 27034, Kampala, Uganda

3 Uganda Wildlife Authority, PO Box 3530, Kampala, Uganda

4 Ecological Trends Alliance, PO Box 36839, Kampala, Uganda

${ }^{5}$ School of Biology, Harold Mitchell Building, University of St Andrews, Fife, KY16 9TH, United Kingdom

${ }^{6}$ Institute of Tropical Forest Conservation, Mbarara University of Science and Technology, PO Box 44, Kabale, Uganda

*Authors for correspondence. e-mail derek@imul.com; ps61@st-andrews.ac.uk

\section{Abstract}

Projected increases in Africa's human population over the next 40 years point to further, large-scale conversion of natural habitats into farmland, with far-reaching consequences for raptor species, some of which are now largely restricted to protected areas (PAs). To assess the importance of PAs for raptors in Uganda, we conducted an annual road survey through savanna, pastoral and agricultural land during 2008-2015. Here, we present density estimates for 34 diurnal raptor species, 17 of which were encountered largely or entirely within PAs. These included seven out of eight globally threatened or near-threatened species surveyed. Based mainly on published demographic values, we converted density estimates (birds $100 \mathrm{~km}^{-2}$ ) to numbers of adult pairs, for 10 resident, savanna-dependent species. We then estimated adult population sizes within conservation areas (individual PAs and clusters of contiguous PAs), based on the area of savanna in each site. This suggested that two threatened residents, Martial Eagle Polemaetus bellicosus and Lappet-faced Vulture Torgos tracheliotos, have national breeding populations of just 53-75 and 74-105 pairs, respectively. A third species, Whiteheaded Vulture Trigonoceps occipitalis, may have a breeding population of just 22-32 pairs. In each case, at least $90 \%$ of pairs are thought to reside within Uganda's five largest conservation areas. In three cases our estimates of pair density were markedly lower than in other studies, while in six cases they were broadly consistent with published findings, often derived using more intensive survey methods. Further work is required to determine the accuracy of our estimates for individual conservation areas, and to assess the long-term viability of Uganda's threatened raptor populations.

Keywords: African raptors, vultures, eagles, raptor abundance, protected areas, savanna 


\section{Introduction}

Many African raptor species are suffering regional or continent-wide declines, driven by a wide range of factors (Thiollay 2006a,b, 2007; Virani et al. 2011; Ogada et al. 2015). Species at greatest risk are those most affected by illegal poisoning, the bushmeat trade, killing for traditional 'medicines', or through collisions with energy infrastructure (Jenkins et al. 2010; Otieno et al. 2010; Virani et al. 2011; McKean et al. 2013; Ogada 2014; Ogada et al. 2015, 2016; Buij et al. 2016). Since vulnerability to these threats often coincides within species, some African raptors now face a perfect storm of adverse conditions.

For slow-breeding, resident species dependent on natural habitats, the on-going expansion of farmland and the degradation of rangelands present further, more pervasive threats, spanning much of Africa. During 1975-2000 almost 5 million hectares of forest and non-forest natural vegetation was destroyed annually in sub-Saharan Africa, resulting in a $21 \%$ reduction in natural vegetation and a $57 \%$ increase in the area of agricultural land (Brink and Eva 2009). This expansion coincided with a rise in the human population, which increased by 0.8 billion during 1960-2016, and is projected to increase by a further 1.8 billion by 2060 (Canning et al. 2015; World Bank 2017a,b). The conversion of savanna, forest and other natural habitats into pastoral and agricultural land is thus set to continue, with far-reaching consequences for most African raptors, and for other savanna-dependent species.

The scale and nature of these changes are important, since many African raptors are more abundant in open- or wooded savanna, than in the farmland habitats that often replace them (Herremans and Herremans-Tonnoeyr 2000; Thiollay 2006c, 2007; Anadón et al. 2010; Buij et al. 2013; Pomeroy et al. 2014). Furthermore, since much of Africa's remaining natural and semi-natural land is now confined to protected areas (PAs), the global populations and ranges of many of its larger, resident raptors are likely to have become highly fragmented.

To fully appreciate the implications of farmland conversion for such species it is important to determine the degree to which they are dependent on protected areas, their density within savanna, and hence the number of pairs each PA is capable of supporting. In a detailed case study, Murn et al. (2016) applied this approach to the White-headed Vulture Trigonoceps occipitalis, a species now largely confined to PAs throughout its global range. Their findings highlight the fragmentary nature of the species' global distribution, showing that $78 \%$ of occupied PAs are each likely to support fewer than five breeding pairs. Furthermore, most of the PAs supporting larger breeding populations (of at least 20 breeding pairs) were separated from other occupied PAs by at least $100 \mathrm{~km}$ (Murn et al. 2016). The insights provided by this approach are key to understanding the population status of Africa's PA-dependent raptors more fully.

One country that has already experienced the transition to a predominantly agricultural landscape is Uganda, whose human population increased by a factor of six during 1960-2016 (World Bank 2017c), coinciding with an expansion in agricultural land over the same period (FAO 2018). To investigate the size and distribution of Uganda's raptor populations, and their dependence on PAs, we conducted a series of annual road surveys spanning 2008-2015. Here, we present abundance estimates for each raptor species within protected savanna, pastoral land and agricultural land, where sample sizes permit. We identify species that were particularly dependent on protected savanna; that is, species we found only in protected savanna, or whose density in savanna was much greater than in pastoral or agricultural land. Based on published demographic values, we estimate the number of adult pairs likely to reside in each protected area, and compare these estimates with breeding densities from elsewhere in Africa. We also examine habitat associations of each species, as a guide to their management within PAs.

\section{Methods}


We recorded the number of individuals of each diurnal raptor species seen whilst driving a series of transects along roads and tracks in Uganda during January (86\% of surveys), February (10\%) or March (4\%), 2008-2015. Since owl species were likely to be substantially under-counted they were excluded from the survey. Transects were of 9-122 km in length (recorded by odometer), and in most cases were surveyed repeatedly over the eight-year period, normally only once each year. The total distance surveyed was $11188 \mathrm{~km}$ (Supplementary Table S1), at a mean of $33 \mathrm{~km} \mathrm{hr}^{-1}$ on public roads (SD = 11.6; $n=44$ transect-years), and $25 \mathrm{~km} \mathrm{hr}^{-1}$ in National Parks ( $\mathrm{SD}=8.9 ; n=57$ transect-years). Observation teams comprised a recorder plus 2-4 observers. In National Parks, and on some tracks outside of the parks, observers gained the widest possible view from the cab roof or by standing behind the cab (in an open pick-up). We refer to these as 'outside observers'. Most transects were surveyed between 09:00 and 17:00, when soaring birds were more likely to be in the air, and hence more visible. Both flying and perched individuals were counted.

Transects followed a network of unpaved tracks in Uganda's four main savanna National Parks

112 (Murchison Falls, Queen Elizabeth, Kidepo Valley and Lake Mburo NPs) and in Bugungu Wildlife Reserve, a buffer area for Murchison Falls NP. They also included public roads from Entebbe to

114 Mbarara, Entebbe to Murchison Falls NP, and from Soroti towards Moroto (Figure 1). Although some birds were identified while the vehicle was moving, we stopped to confirm the identity of most birds seen, particularly those in groups. Rarely, additional raptors were seen as a result of stopping, and were included in the count. Time spent stationary was included in the transect duration.

Each transect was assigned to one of three land use categories: savanna, pastoral land or agricultural land. Savanna transects followed unpaved tracks through open- or wooded grassland within the protected areas named above. Pastoral transects were on public roads through vegetation that was often superficially similar in structure and species composition to that of natural, protected savanna, but lay outside of protected areas, where wild herbivores were largely or wholly replaced by livestock. Agricultural transects also followed public roads, but through land supporting a range of crops, almost all of them in small fields, typically interspersed with patches of non-native trees, e.g. Eucalyptus species. Most pastoral transects included small areas of agricultural land and vice-versa. Both of these transect types included human settlements, mainly small trading centres. For each transect we also recorded the mean altitude (from topographical maps), mean annual rainfall (from Government of Uganda 1967) and tree cover. The latter was defined as: open grassland, light tree cover, heavy tree cover, or closed canopy (i.e. forest). A small proportion of transects within PAs were predominantly tree covered, dominated by Acacia and Combretum spp.

The migratory status of each species was defined as: resident, Palearctic migrant, or Afrotropical migrant (after Buij et al. 2013). One species (Common Kestrel Falco tinnunculus) has both migratory and resident populations in East Africa (Zimmerman et al. 1996; Brown et al. 1997).

\section{Abundance estimates}

140 The perpendicular distance of each bird from the road or track (when first seen) was estimated and assigned to one of four distance bands; 0-100, 100-200, 200-500 and >500 m. Detections made in the furthest band were subsequently discarded, since its outer limit was not defined. Four key functions (half-normal, hazard-rate, uniform and negative-exponential) were applied, using Distance V6.0, Release 2 (Thomas et al. 2010). Since the negative-exponential function is no longer recommended (Thomas et al. 2010), we selected from among the three remaining functions, using Akaike's Information Criterion (AIC), lower AIC values indicating an improved fit, requiring fewer parameters. For each species we used a Kruskal-Wallis test to determine whether the proportion of sightings made in each distance band varied significantly in relation to land use. If so, we applied a Conventional Distance Sampling model to data from each land use type separately. Otherwise, we used Multiple Covariate Distance Sampling (MCDS; Marques et al. 2007; Thomas et al. 2010), stratifying by land use. 
The public roads surveyed within agricultural and pastoral land were closely associated with homesteads, villages and trading centres, and supported a moderate volume of traffic. These factors almost certainly reduced the roadside densities of some raptors, while boosting numbers of synanthropic species. Since density estimates derived from agricultural and pastoral transects were unlikely to have been representative of these forms of land use generally, we did not attempt to estimate population sizes within agricultural or pastoral land. In contrast, density estimates derived from transects through protected savanna were much less likely to have been influenced by these confounds, since people and infrastructure were virtually absent, traffic was both scarce and slowermoving, and roadkill less evident than on public roads. We therefore estimated species' population sizes within protected areas by multiplying their density in protected savanna by the area of this land use type in Uganda.

164 Land use estimates were provided by the National Biodiversity Data Bank, using data extracted from WCS \& eCountability (2016). Estimates were obtained by first summing the area of all land classed either as moist or dry savanna, and adding $50 \%$ of the land area classed either as forest-savanna mosaic or as seasonal wetland. This calculation was made for 646 PAs of three types: National Parks, Wildlife Reserves and Forest Reserves (Supplementary Table S4). A further 66 Forest Reserves (each of less than $1 \mathrm{~km}^{2}$ ) were excluded, since most of these were known to have been converted to agricultural production or to exotic tree plantations (National Biodiversity Data Bank in litt.). Of the 646 PAs considered, some were contiguous with other PAs, yielding more extensive blocks of savanna than they would have, had they been surrounded by farmland. We therefore identified clusters of contiguous PAs, and calculated the total area of savanna within each cluster, rather than treating its component PAs as separate sites. Eleven such clusters, encompassing 33 PAs, were included in our final list. Hereafter, we refer to both isolated PAs and clusters of contiguous PAs as 'conservation areas' (CAs) (Supplementary Table S4). An additional site designation, 'Community Wildlife Management Areas', was excluded from the analysis, since these largely comprise pastoral land, and typically support only sparse populations of natural prey (D.P. pers. obs.).

180 We identified species that showed a strong affinity for protected savanna, and hence for conservation areas, based on the species' much higher density in savanna compared with pastoral and agricultural land (from Table 1). Each species was scored as follows: 1 . species encountered only in protected savanna (during this study), or too few encounters recorded in pastoral or agricultural land to be able to estimate densities in these land use types; 2 . species whose density in protected savanna was at least four times that in pastoral or agricultural land; 3. all remaining species.

For resident species in categories 1 or 2 we estimated the number of pairs likely to reside in each CA, as follows. First, we estimated the number of individuals present of all ages, from the species' density in savanna and the total area of savanna present. We used published estimates from study populations to estimate the proportion of birds likely to be adult, and hence of breeding age. Where published demographic values were lacking, we assumed that adults accounted for $65 \%$ of the population, this being the mean percentage for the five species for which published estimates were available. For each species we estimated the number of pairs of adults likely to be present, in two scenarios: where all adults were paired; and where $75 \%$ of adults were paired. We further assumed that small CAs, with sufficient savanna to support only a single pair of a given species, would be occupied only intermittently. Following Murn et al. (2016), we took a conservative approach to estimating the number of breeding pairs present, by excluding CAs where the amount of savanna was less than double that required to support one pair of the target species.

\section{Habitat associations}

We investigated the relationship between the number of individuals encountered on each survey of a given transect, and potential explanatory variables, using generalised linear mixed models (GLMMs). These were fitted using the glmer function in the Ime4 package in R (3.0.1; R Development Core Team 
2016). Each case in the dataset represented one transect-year, i.e. one survey of a given transect in a given year. The explanatory variables included were: land use type; transect length; mean altitude; mean annual rainfall; tree cover category; and the presence of 'outside' observers. Since multiple surveys were made from each transect, sometimes in the same year, we specified 'transect identity' and 210 'year' as random terms in each model.

212 In most cases, few or no individuals of a given species were encountered in a given transect-year. Hence, the distribution of the dependent variable (the number of individuals encountered) was often

214 highly skewed. We therefore examined the relationship between the number of individuals encountered and potential explanatory variables using two model structures. First, we identified explanatory variables associated with the presence/absence of a given species, specifying a binomial error distribution. In the second model we restricted the dataset to cases where at least one individual of the target species had been recorded, and specified a Poisson error distribution. For each model type, minimal models were derived through stepwise elimination of the least significant explanatory variable, as recommended in Crawley (2005). Final models were those with the lowest AIC value.

222

\section{Results}

224

226

\section{Population densities}

Densities were estimated for 34 raptor species; 12 in arable land, 18 in pastoral land and for all 34 in protected savanna (Table 1). Fifteen (44\%) of the 34 species were encountered only in savanna, or else so sparsely in farmland that it was not possible to estimate their densities there. Of those species for which density estimates could be made in pastoral or agricultural land, two occurred at much lower densities $(<25 \%)$ than they attained in savanna. Thus, 17 raptor species appeared to be almost exclusively associated with savanna, and were therefore largely or wholly restricted to conservation areas. Our density and population estimates for one species, African Fish Eagle Haliaeetus vocifer, were likely to have been misleading, since the species is closely associated with linear aquatic features (rivers and lake shores), and is widespread in (unprotected) freshwater habitats. Consequently, we have excluded this species from further abundance analyses, leaving 16 'savanna-dependent' species (Table 2). Note, however, that the confidence limits (CLs) associated with these density estimates were typically wide, showing extensive overlap for the same species in savanna and pastoral or agricultural land (Table 1).

\section{Fragmentation effects}

244 Based on land use data provided by WCS \& eCountability (2016), we estimated that savanna habitats covered $22308 \mathrm{~km}^{2}$ in Uganda in 2010, all of it within conservation areas (CAs). We have used this

246 figure to estimate the number of individuals present in Uganda's CAs, for each of the 16 savannadependent species, by multiplying the total area of protected savanna (above) by each species' density within savanna (Table 2). This approach is likely to have over-estimated population sizes, however, since our savanna area figure includes many small fragments. Of the 624 conservation areas identified, $49 \%$ contained less than $1 \mathrm{~km}^{2}$ of savanna, and were therefore unlikely to support even a single pair of the species in question. Conversely, the five largest CAs each contained $>1,000 \mathrm{~km}^{2}$ of savanna, and together accounted for $63 \%$ of the total area of protected savanna.

Fragmentation of the available habitat is likely to impact mainly on resident species, particularly those defending large, year-round breeding territories, and colony-nesters requiring very extensive areas of savanna in which to forage (e.g. the Gyps species). Of the 16 savanna-dependent species, 10 are resident in Uganda and are known or likely to breed there. Based on estimates of the proportion of adult birds in the population, and assuming that $75-100 \%$ of adults were paired, at least half of these species are likely to have breeding populations of fewer than 100 pairs (Table 3). They include Martial Eagle 

White-headed Vulture (22-32 pairs). In each case, at least $90 \%$ of pairs are likely to reside within the five largest conservation areas (Table 3).

264 To gauge the effects of fragmentation on species' populations we compared the numbers of adult pairs estimated using the above approach (Table 3), with the number derived by multiplying pair density by the total area of savanna in Uganda (Table 2). That is, we compared population estimates that take account of resource fragmentation, with those in which fragmentation was disregarded. Not surprisingly, national estimates for the 10 resident, savanna-dependent species were all lower when fragmentation was taken into account; by a median of 41\% (quartiles: 30-48\%) (Figure 2).

\section{Habitat associations}

274 Binomial GLMMs indicated that 11 species were more likely to be detected from savanna transects than from pastoral or agricultural transects (Table 4; Supplementary Table S2). A further three species were more likely to be detected from savanna or pastoral transects, when the data from these were pooled, suggesting that the species were attracted by features common to both but missing from agricultural land. Of these 14 species, five are classed as globally threatened and one as near-threatened. Not surprisingly, this group includes the larger, resident eagles (Martial Eagle and Bateleur Terathopius ecaudatus) as well as three vulture species (White-backed G. africanus, Rüppell's G. rueppelli and Whiteheaded Vulture). Land use preferences of a fourth species, Lappet-faced Vulture, could not be modelled in the same way, due to its absence from pastoral and agricultural transects. Among nine species that were more likely to be detected from pastoral transects, or from pastoral and agricultural transects in combination, only one (Hooded Vulture Necrosyrtes monachus) is globally threatened (Table 4). Thus, seven out of eight globally threatened or near-threatened species were significantly associated with, or restricted to, protected savanna.

In GLMMs fitted with a Poisson error distribution, and restricted to cases where the target species was seen, four species (Steppe Eagle Aquila nipalensis, Tawny Eagle A. rapax, Bateleur and Grey Kestrel F. ardosiaceus) were more abundant on savanna transects than elsewhere. Only one species (Whiteheaded Vulture) was more abundant on pastoral transects, and one (Hooded Vulture) on pastoralagricultural transects combined (Table 4).

Five species were more likely to be encountered on transects where tree cover was absent or light, while two were positively associated with denser tree cover. Similarly, four species were more abundant where tree cover was absent, while two were more abundant in denser tree cover. The latter included Rüppell's Vulture, which, although more often seen from transects in open or lightly-wooded grassland, occurred in larger numbers when encountered in more wooded habitat (Table 4).

\section{Discussion}

304 Driven line transects are one of the most widely used methods for measuring raptor abundance in Africa. However they tend to yield a biased estimate of bird density, since conditions adjacent to roads and tracks will often differ from those in the wider landscape. Here, transects on public roads running through pastoral and agricultural land were associated with moderate levels of traffic disturbance, infrastructure development, housing and vegetation changes, and were considered unlikely to yield raptor densities representative of these two land use types. In particular, species deterred by these factors may have been more abundant at greater distances from public roads within pastoral and agricultural land. If so, our figures may tend to over-estimate any differences between these land use types and the densities attained in protected savanna, where the level of bias associated with (unpaved) survey routes was likely to have been lower, and the roadside densities we recorded were more likely 
to have been representative of protected savanna generally. Nonetheless, we note that foot transects consistently yield higher raptor densities than driven transects, particularly of smaller species (D.P.

316 pers. obs.).

318 Pomeroy et al. (2014) estimated population densities and sizes of six vulture species in Uganda, using data from the first six years of the survey described here, i.e. during 2008-2013. Not surprisingly, their density estimates within protected savanna were similar to those presented here. However, their population estimates differed substantially, for two reasons. First, using an earlier land cover dataset, they estimated that the area of savanna within Uganda's PA network was much lower (9573 $\left.\mathrm{km}^{2}\right)$ than the figure used in this study $\left(22308 \mathrm{~km}^{2}\right)$. The latter was drawn from a more recent and, we believe, more accurate assessment (WCS \& eCountability 2016). Second, Pomeroy et al. (2014) treated all savanna as a single block when estimating national population sizes, ignoring the effects of fragmentation, illustrated here in Figure 2.

328 We estimated the number of adult pairs of each resident, savanna-dependent species likely to reside within Uganda's conservation areas. Although in some species immatures may also form pairs, we have focused on adult pairs, which are more likely to attempt to breed, and to do so successfully. We therefore estimated the proportion of birds likely to be adult and paired, and then calculated the area of savanna available to each adult pair. We used this value to exclude sites in which the amount of savanna available was likely to be too small to support a single adult pair. Since it would have been impractical to try to assess the age of each bird seen, the proportion of adults in the population was estimated from published findings. In the absence of these data we assumed that $65 \%$ of the population were adult, this being the median value for those species for which data were available. We further assumed that, for resident, savanna-dependent species, $75-100 \%$ of adults were paired (Table 3 ). Since the upper figure is probably attained only rarely, we have used the lower figure when discussing the 10 species largely confined to conservation areas.

Our estimates of the numbers of adult pairs present within conservation areas could prove conservative, given that most of the 10 savanna-dependent species are likely to be capable, to some degree, of exploiting adjacent pastoral land, or of regularly crossing farmland to reach other, nearby conservation areas. If so, some of the sites we rejected as being too small to accommodate a given species may be occupied, and hence the species may prove to be more abundant than our estimates suggest.

\section{Vultures}

Murn et al. (2016) demonstrated the value of using nest densities and demographic parameters to refine estimates of the global population size of White-headed Vulture, a species highly dependent on Africa's PA network. They estimated a global population of 5 475-5 493 birds; much lower than a long-

354 standing estimate of 7 000-12 000 birds (Mundy et al. 1992), and more precise than the population size category in which the species is currently placed by BirdLife International (2018): 2 500-9 999 mature individuals.

358 Here, we estimated that the area of savanna available to White-headed Vulture pairs in Uganda averaged $472 \mathrm{~km}^{2}$ pair-1; slightly higher than the value used by Murn et al. (2016) for East African populations ( $400 \mathrm{~km}^{2}$ pair-1), based on their density in the Serengeti ecosystem (Pennycuick 1976). Murn et al. (2016) estimated that Uganda's PA series was likely to support 12.2 breeding pairs of Whiteheaded Vulture, distributed across 13 sites. Since they assumed that only $75 \%$ of pairs attempt to breed in any given year, this translates into 16.3 pairs (breeding and non-breeding); fewer than the 22 pairs (in five conservation areas) estimated here (Table 3). This disparity may stem from differences in the area figures used in the two studies. Murn et al. (2016) assumed that each PA consisted entirely of suitable habitat, but that land close to the PA boundary was likely to be less suitable than core areas (following Herremans and Herremans-Tonnoeyr 2000). Their population estimates were thus based on 
the entire area of the site (rather than the area of savanna present), from which they subtracted a fixed area $\left(50 \mathrm{~km}^{2}\right)$, to account for likely boundary effects. In contrast, our estimates were based on the

370 amount of savanna present, which accounted for $72 \%$ of the land within conservation areas, the remainder comprising less suitable habitat, including wetlands and rain forest. Furthermore, we

372 measured the combined area of savanna within clusters of contiguous sites, whereas Murn et al. (2016) treated each site as a discrete area, rejecting PAs that were individually too small to support Whiteheaded Vulture pairs, even where they were contiguous with other savanna sites.

376 In this study, White-headed Vultures were significantly more likely to be detected from savanna transects than from pastoral or agricultural transects, but were significantly more abundant on pastoral transects (Table 4). This finding is likely to prove misleading, however, as it is based partly on a count of seven birds seen once on a single pastoral transect; all (26) other sightings were made on savanna transects, involving lower numbers per transect.

382 Lappet-faced Vultures are largely confined to conservation areas, which we estimate to hold some 74 pairs, distributed among nine CAs, with $c .93 \%$ of pairs residing in the five largest CAs. These figures are 384 derived from the area of savanna available per pair, which we estimated at $184 \mathrm{~km}^{2}$. This figure is a little higher than estimates derived from nest counts made during aerial surveys in Swaziland $\left(147 \mathrm{~km}^{2}\right.$ pair-1; from Monadjem and Garcelon 2005; Bamford et al. 2009) and Zululand, S Africa (149 km² pair-1; from Bamford et al. 2009) (Table S3). Equivalent estimates from other PAs vary widely however; from $256 \mathrm{~km}^{2}$ pair-1 in Kruger NP, S Africa (Murn et al. 2013) to just $43 \mathrm{~km}^{2}$ pair-1 in the Serengeti ecosystem (Pennycuick 1976), where carcass availability was presumably much higher.

Uganda's conservation areas are also likely to support the equivalent of 828 and 222 pairs of Whitebacked and Rüppell's Vultures, at a density of one pair per $22 \mathrm{~km}^{2}$ and $71 \mathrm{~km}^{2}$, respectively. For Whitebacked Vulture, similar densities have been reported from aerial counts of nests in Hwange NP, Zimbabwe (27 km² pair-1; Howells and Hustler 1984), Linyanti, Botswana (23 km² pair-1; Bamford et al. 2009) and Kruger NP (22 and $32 \mathrm{~km}^{2}$ pair-1; Monadjem et al. 2012; Murn et al. 2013). However, much higher densities have been reported from aerial counts of tree colonies in Swaziland $\left(2 \mathrm{~km}^{2}\right.$ pair-1; from Bamford et al. 2009), Zululand (5 km² pair-1; from Bamford 2009) and Kimberley, SA (1.7 km² pair-1; Murn et al. 2017). While Virani et al. (2010) reported similarly high densities (0.7-2.8 $\mathrm{km}^{2}$ pair-1) from a ground-based survey in Masai Mara GR, Kenya, they noted that the (mainly riverine) areas they sampled were unlikely to be representative of the entire Masai Mara ecosystem. No comparable density estimates were found for Rüppell's Vulture.

The population of Palm-nut Vulture Gypohierax angolensis in Uganda's conservation areas is likely to include some 222 pairs, occupying 15 CAs. We estimate that the amount of savanna available per pair was $71 \mathrm{~km}^{-2}$, suggesting that suitable habitat is very patchily distributed. A much lower estimate, of 2 $\mathrm{km}^{2}$ pair-1, has been reported from Cote d'Ivoire, but was considered exceptional (Brown et al. 1997).

\section{Eagles}

Uganda's conservation areas encompass sufficient savanna to support some 53 pairs of Martial Eagle, across seven CAs. Our estimate of the mean area available pair-1 $\left(241 \mathrm{~km}^{2}\right)$ was higher than in the Masai Mara (120 km² pair-1; Ong 2000), Hwange NP (133 km²; Hustler and Howells 1987) and Kruger NP: 108-194 km² pair-1 (Snelling 1970; Herholdt and Kemp 1997; van Eeden et al. 2017), but lower than in Tsavo East NP, Kenya (300 km² pair-1.; Smeenk 1974). Not surprisingly, lower densities have been recorded in desert or semi-desert habitat: Kalahari Gemsbok NP, South Africa supported 20-30 pairs (at 320-480 km² pair-1) in 1988-1994, dropping to just nine breeding pairs (889 $\mathrm{km}^{2}$ pair-1) by 20112012 (Herholdt and Kemp 1997; Amar et al. 2016).

420 The mean area of protected savanna available to Bateleur pairs $\left(21 \mathrm{~km}^{2}\right.$ pair-1) was much lower than has been reported from Kenya (170 km² pair-1; Brown et al. 1997), but closer to that recorded in Kruger 
422 NP: 3.1 nests $100 \mathrm{~km}^{-2}$; equivalent to $32 \mathrm{~km}^{2}$ nest-1 (Watson 1990a,b). When adjusted to account for non-breeding pairs (16\% of pairs p.a.; Watson 1990b), the area available to each pair will have been lower, averaging $27 \mathrm{~km}^{2}$ pair-1, i.e. closer to our estimate. Nonetheless, we feel that our population estimate for Uganda's conservation areas (862 pairs in 54 CAs) should perhaps be treated with caution.

Density estimates for African Hawk-eagle A. spilogaster in southern Africa range between 19 and $33 \mathrm{~km}^{2}$ pair-1 in Kruger NP and Matobo, Zimbabwe (Snelling 1970; Steyn 1975), and 18-59 km² pair-1 in Hwange NP (Hustler and Howells 1988). Similarly, in East Africa, Smeenk (1974) reported an average territory size of $56 \mathrm{~km}^{2}$ pair $^{-1}$ in Tsavo East NP. In contrast, our density estimate was extremely low, despite the species being widespread in East Africa, including Uganda. We recorded a density of just 0.29 birds $100 \mathrm{~km}^{-2}$, suggesting that suitable habitat was very patchily distributed, or that the species was substantially under-recorded from driven line transects. Reasons for the disparity between our figures and those derived from more intensive studies thus remain unclear.

In tropical Africa, Black-chested Snake-eagle Circaetus pectoralis and its congeners occur at low densities, each pair requiring 'several hundred $\mathrm{km}^{2}$ ' (Brown et al. 1997). This suggests that our very low density estimate (384 $\mathrm{km}^{2}$ pair-1), may be broadly accurate, yielding a population estimate of $c$. 30 pairs, in the five largest CAs.

\section{Red-necked Falcon F. ruficollis}

444 Our Red-necked Falcon density estimate (342 $\mathrm{km}^{2}$ pair-1) differed markedly from published estimates. Nests have been found as little as 1.3-3.2 km apart in Zambia and 1.9-15.5 km apart in South Africa, although these spacings were regarded as exceptional (Tarboton 2001). Inter-nest distances of 3-10 $\mathrm{km}$, indicating densities of 7-78 $\mathrm{km}^{2}$ pair-1, are regarded as being more typical in southern Africa (Tarboton 2001), while a density of $167 \mathrm{~km}^{2}$ pair-1 has been recorded in the central Namib (Brown 1988). Our low density estimate suggests that conditions appropriate for the species are extremely patchily distributed in Uganda's conservation areas. This may reflect the species' association with Borassus Palm Borassus aethiopum, which is generally scarce in most of Uganda (D.P., pers. obs.)

\section{Conclusions}

Road surveys within four of Uganda's National Parks yielded raptor densities that were in most cases broadly comparable with published estimates derived from other studies, most of which involved ground-based nest monitoring or expensive aerial surveys (Table S3). For Uganda's globally threatened species at least, further work is required to determine whether the estimates presented here accurately reflect the numbers of adult pairs present within the National Parks surveyed; and whether they are equally applicable to other forms of PA, as well as to smaller conservation areas generally. There is also a pressing need to assess the viability of threatened raptor species particularly dependent on Uganda's conservation areas, namely Martial Eagle, Lappet-faced, White-headed, Rüppell's and White-backed Vulture. Breeding populations of the first three species are both sparse and fragmented, placing their long-term viability in Uganda in doubt. While the breeding status of the two Gyps vultures is unclear, there is strong evidence that they can make long-distance movements within Uganda (Pomeroy 2008), and are likely to be part of a regional meta-population. This will need to be so for all species with fragmented populations if they are to survive in the long term. Much more needs to be known of the populations and movements of these five species, to help secure their Ugandan populations in perpetuity.

\section{Acknowledgements}


We thank Uganda Wildlife Authority for granting us permission to make road counts in protected areas, and for providing their most experienced rangers to assist with the survey. Several volunteers from NatureUganda acted as recorders. Our thanks go to Taban Bruhan, Judith Mirembe, Roger Skeen, Lydia Tushabe and Lilian Twanza. Roger Skeen also kindly provided count data for Kidepo Valley National Park. Murn Campbell and Darcy Ogada made valuable comments on the manuscript. We are especially grateful to Will Cresswell for providing guidance on modelling in $R$. We also thank Alan Lee, Steffen Oppel and an anonymous reviewer for their comments. The cost of field work was generously covered by The Peregrine Fund (USA) and the Royal Society for the Protection of Birds (UK).

\section{References}

Amar A, Cloete D, Whittington M. 2016. Using independent nest survey data to validate changes in reporting rates of Martial Eagles between the Southern African Bird Atlas Project 1 and 2. Ostrich 87: 1-5, DOI: 10.2989/00306525.2015.1089333

Anadón JD, Sánchez-Zapata JA, Carrete M, Donázar JA, Hiraldo F. 2010. Large-scale human effects on an arid African raptor community. Animal Conservation 13: 495-504.

Anderson MD. 2000. African White-backed Vulture. In: K.N. Barnes (ed.). The Eskom Red Data Book of birds of South Africa, Lesotho and Swaziland. BirdLife South Africa, Johannesburg. 169 pp.

Bamford AJ, Monadjem A, Anderson MD, Anthony A, Borello WD, Bridgeford M, Bridgeford P, Hancock P, Howells B, Wakelin J, Hardy ICW. 2009. Trade-offs between specificity and regional generality in habitat association models: a case study of two species of African vulture. Journal of Applied Ecology 46(4): 852-860. doi: 10.1111/j.1365-2664.2009.01669.x

BirdLife International 2018. IUCN Red List for birds. Downloaded from http://www.birdlife.org on $31 / 01 / 2018$

Brink AB, Eva HD. 2009. Monitoring 25 years of land cover change dynamics in Africa: a sample based remote sensing approach. Applied Geography 29: 501-512.

Brown CJ. 1988. Greater Kestrel and Rednecked Falcon populations in the Ganab region of the central Namib Desert. Gabar 3: 21-25

Brown LH, Urban EK, Newman K. 1997. The Birds of Africa. Volume I. Academic Press: London, UK

Buij R, Croes BM, Gort G, Komdeur J. 2013. The role of breeding range, diet, mobility and body size in associations of raptor communities and land-use in a West African savanna. Biological Conservation 166: 231-246.

Buij R, Nikolaus G, Whytock R, Ingram D, Ogada D. 2016. Trade of threatened vultures and other raptors for fetish and bushmeat in West and Central Africa. Oryx 50(4): 606-616. doi:10.1017/S0030605315000514

Canning D, Raja S, Yazbeck AS. 2015. Africa's Demographic Transition: Dividend or Disaster? Overview booklet. Africa Development Forum series. World Bank: Washington, DC. License: Creative Commons Attribution CC BY 3.0 IGO

Crawley MJ. 2005. Statistics: an introduction using R. Chichester: John Wiley and Sons.

514 FAO 2018. http://www.fao.org/faostat/en/\#country/226 Downloaded 04/04/2018

Government of Uganda 1967. Atlas of Uganda 2nd Edition. Entebbe, Uganda: Department of Lands and Surveys

Herholdt JJ, Kemp AC. 1997. Breeding status and ecology of the Martial Eagle in the Kalahari Gemsbok National Park, South Africa. Ostrich 68(2-4): 80-85. DOI: 10.1080/00306525.1997.9639717

Herremans M, Herremans-Tonnoeyr D. 2000. Land use and the conservation status of raptors in Botswana. Biological Conservation 94: 31-41. 
Howells WW, Hustler K. 1984. The status and breeding success of eagles and vultures in the Hwange National Park, Zimbabwe. In: Mendelsohn, JM, Sapsford, CW. (eds.), Proceedings of the Second Symposium on African Predatory Birds. Durban: Natal Bird Club. pp 99-107.

Hustler K, Howells WW. 1987. Breeding periodicity, productivity and conservation of the Martial Eagle. Ostrich 58(3): 135-138.

Hustler K, Howells WW. 1988. The effect of primary production on breeding success and habitat selection in the African Hawk-eagle. The Condor 90: 583-587.

Jenkins AR, Smallie JJ, Diamond M. 2010. Avian collisions with power lines: a global review of causes and mitigation with a South African perspective. Bird Conservation International 20: 263-278.

Kemp AC, Kirwan GM. 2018. Palm-nut Vulture (Gypohierax angolensis). In: del Hoyo J, Elliott A, Sargatal J, Christie DA, de Juana E. (eds.). Handbook of the Birds of the World Alive. Lynx Edicions, Barcelona. (retrieved from https://www.hbw.com/node/52991 on 21 February 2018)

Marques TA, Thomas L, Fancy SG, Buckland ST. 2007. Improving estimates of bird density using multiple covariate distance sampling. The Auk 124: 1229-1243.

McKean S, Mander M, Diederichs N, Ntuli L, Mavundla K, Williams V, Wakelin J. 2013. The impact of traditional use on vultures in South Africa. Vulture News 65: 15-36.

Monadjem A, Garcelon DK. 2005. Nesting distribution of vultures in relation to land use in Swaziland. Biodiversity and Conservation 14: 2079-2093. DOI 10.1007/s10531-004-4358-9

Monadjem A, Botha A, Murn C. 2012. Survival of the African white-backed vulture Gyps africanus in north-eastern South Africa. African Journal of Ecology 51: 87-93.

Mundy P, Butchart D, Ledger J, Piper S. 1992. The Vultures of Africa. South Africa: Acorn Books

Murn C, Anderson MD, Anthony A. 2002. Aerial survey of African white-backed vulture colonies around Kimberley, Northern Cape and Free State provinces, South Africa. South African Journal of Wildlife Research 32(2): 145-152.

Murn C, Combrink L, Ronaldson GS, Thompson C, Botha A. 2013. Population estimates of three vulture species in Kruger National Park, South Africa. Ostrich: Journal of African Ornithology. DOI:10.2989/00306525.2012.757253

Murn C, Mundy P, Virani MZ, Borello WD, Holloway GJ, Thiollay J-M. 2016. Using Africa's protected area network to estimate the global population of a threatened and declining species: a case study of the Critically Endangered White-headed Vulture Trigonoceps occipitalis. Ecology and Evolution doi: 10.1002/ece3.1931

Murn C, Botha A, Wilson B. 2017. The changing sizes of critically endangered White-backed Vulture breeding colonies around Kimberley, South Africa. African Journal of Wildlife Research 47(2): 144148

Ogada DL. 2014. The power of poison: pesticide poisoning of Africa's wildlife. Annals of the New York Academy of Sciences 1322: 1-20.

Ogada D, Shaw P, Beyers RL, Buij R, Murn C, Thiollay JM, Beale CM, Holdo RM, Pomeroy D, Baker N, Krüger SC, Botha A, Virani MZ, Monadjem A, Sinclair ARE. 2015. Another Continental Vulture Crisis: Africa's Vultures Collapsing toward Extinction. Conservation Letters 9: 89-97. DOI: $10.1111 /$ conl.12182

Ogada D, Botha A, Shaw P. 2016. Ivory poachers and poison; drivers of Africa's declining vulture populations. Oryx 50(4): 593-596. DOI: https://doi.org/10.1017/S0030605315001209

Ong CD. 2000. The home range of the Martial Eagle Polemaetus bellicosus determined with the use of radio telemetry. University of Leicester

Otieno PO, Lalah JO, Virani M, Jondiko IO, Schramm K-W. 2010. Carbofuran and its toxic metabolites provide forensic evidence for furadan exposure in vultures (Gyps africanus) in Kenya. Bulletin of Environmental Contamination and Toxicology 84: 536-544. 
Pennycuick CJ. 1976. Breeding of the lappet-faced and white-headed vultures (Torgos tracheliotus Forster and Trigonoceps occis Burchell) on the Serengeti Plains, Tanzania. East African Wildlife Journal 14: 67-84

Pomeroy D. 2008. Raptor migrations in western Uganda - spring 2007 and 2008. Gabar 19: 68-70.

Pomeroy D, Shaw P, Opige M, Kaphu G, Ogada DI, Virani MZ. 2014. Vulture populations in Uganda: using road survey data to measure both densities and encounter rates within protected and unprotected areas. Bird Conservation International 25(4): 399-414. DOI: 10.1017/S095927091400029X

R Development Core Team. 2016. R: a language and environment for statistical computing. R Foundation for Statistical Computing, Vienna

Smeenk C. 1974. Comparative ecological studies of some East African birds of prey. Ardea 62: 1-97

Snelling JC. 1970. Some information obtained from marking large raptors in the Kruger National Park, Republic of South Africa. Ostrich supplement. 8: 415-427

Steyn P. 1975. Observations on the African Hawk-Eagle. Ostrich 46: 87-105

Tarboton W. 2001. A Guide to the Nests and Eggs of Southern African Birds. Struik Publishers Ltd, Cape Town.

Thiollay JM. 2006a. Severe decline of large birds in the Northern Sahel of West Africa: a long-term assessment. Bird Conservation International 16: 353-365.

Thiollay JM. 2006b. The decline of raptors in West Africa: long-term assessment and the role of protected areas. Ibis 148: 240-254.

Thiollay JM. 2006c. Large bird declines with increasing human pressure in savanna woodland (Burkina Faso). Biodiversity \& Conservation 15: 2085-2108.

Thiollay JM. 2007. Raptor declines in West Africa: comparisons between protected, buffer and cultivated areas. Oryx 41(3): 322-329.

Thomas L, Buckland ST, Rexstad EA, Laake JL, Strindberg S, Hedley SL, Bishop JRB, Marques TA, Burnham KP. 2010. Distance software: design and analysis of distance sampling surveys for estimating population size. Journal of Applied Ecology 47: 5-14.

van Eeden R, Whitfield DP, Botha A, Amar A. 2017. Ranging behaviour and habitat preferences of the Martial Eagle: Implications for the conservation of a declining apex predator. PLOS ONE 12(3): e0173956. https://doi.org/10.1371/journal.pone.0173956

Virani MZ, Kirui P, Monadjem A, Thomsett S, Githiru M. 2010. Nesting status of African White-backed Vultures Gyps africanus in the Masai Mara National Reserve, Kenya. Ostrich 81: 205-209.

Virani MZ, Kendall C, Njoroge P, Thomsett S. 2011. Major declines in the abundance of vultures and other scavenging raptors in and around the Masai Mara ecosystem, Kenya. Biological Conservation 144: 746-752

Watson RT. 1990a. Population dynamics of the Bateleur in the Kruger National Park. Ostrich 61: 5-12.

Watson RT. 1990b. Breeding biology of the Bateleur. Ostrich 61: 13-23.

WCS \& eCountability. 2016. Land cover analysis of Langdale-Brown et al in comparing vegetation classification and land use change. Wildlife Conservation Society, Kampala, Uganda.

World Bank. 2017a. https://data.worldbank.org/indicator/SP.POP.GROW?name desc=false Downloaded 05/09/2017

World Bank. 2017b. https://data.worldbank.org/region/sub-saharan-africa. Downloaded 18/12/2017

World Bank. 2017c. https://data.worldbank.org/country/uganda. Downloaded 18/12/2017

Zimmerman DA, Turner DA, Pearson DJ. 1996. Birds of Kenya and Northern Tanzania. C. Helm, A\&C Black, London, UK. 
612 Table 1: Density estimates (birds $100 \mathrm{~km}^{-2}$ ) in relation to land use. Figures are presented only for species-land use combinations yielding sufficient encounters with which to estimate density using Distance sampling

\begin{tabular}{|c|c|c|c|c|c|c|c|c|}
\hline Species & Land use ${ }^{1}$ & $n^{2}$ & Model $^{3}$ & $\begin{array}{l}\text { Detection } \\
\text { function }\end{array}$ & Adjustments $^{4}$ & ESW $^{5}$ & Density & CLs \\
\hline African Hawk-eagle & Savanna & 16 & CDS & Uniform & & 500 & 0.29 & $(0.16-0.54)$ \\
\hline \multicolumn{9}{|l|}{ Aquila spilogaster } \\
\hline Steppe Eagle & Savanna & 72 & MCDS & Half normal & & 193 & 3.40 & $(1.27-9.13)$ \\
\hline A. nipalensis & Pastoral & 12 & MCDS & Half normal & & 102 & 2.51 & $(0.55-11.32)$ \\
\hline Tawny Eagle & Savanna & 135 & MCDS & Half normal & & 226 & 5.46 & $(3.67-8.13)$ \\
\hline A. rapax & Pastoral & 20 & MCDS & Half normal & & 243 & 1.76 & $(0.92-3.36)$ \\
\hline Black-chested Snake-eagle & Savanna & 34 & CDS & Uniform & Cos. 1 & 291 & 1.07 & $(0.63-1.80)$ \\
\hline \multicolumn{9}{|l|}{ Circaetus pectoralis } \\
\hline Brown Snake-eagle & Agricultural & 27 & CDS & Half normal & & 241 & 1.75 & $(0.96-3.19)$ \\
\hline \multirow[t]{2}{*}{ C. cinereus } & Savanna & 90 & CDS & Half normal & & 206 & 3.99 & $(2.87-5.55)$ \\
\hline & Pastoral & 30 & CDS & Uniform & Cos. 1 & 251 & 2.55 & $(1.47-4.42)$ \\
\hline Short-toed Snake-eagle & Savanna & 18 & CDS & Half normal & & 294 & 0.56 & $(0.25-1.25)$ \\
\hline \multicolumn{9}{|l|}{ C. gallicus } \\
\hline Western Banded Snake-eagle & Savanna & 13 & MCDS & Half normal & & 142 & 0.84 & $(0.38-1.85)$ \\
\hline C. cinerascens & Pastoral & 12 & MCDS & Half normal & & 181 & 1.41 & $(0.62-3.23)$ \\
\hline African Fish-eagle & Savanna & 135 & MCDS & Half normal & & 199 & 6.19 & $(4.39-8.72)$ \\
\hline \multicolumn{9}{|l|}{ Haliaeetus vocifer } \\
\hline Wahlberg's Eagle & Agricultural & 34 & MCDS & Half normal & & 176 & 3.01 & $(1.63-5.56)$ \\
\hline \multirow[t]{2}{*}{ H. wahlbergi } & Savanna & 29 & CDS & Uniform & Cos. 1 & 256 & 1.04 & $(0.64-1.68)$ \\
\hline & Pastoral & 36 & MCDS & Half normal & & 193 & 3.97 & $(1.80-8.76)$ \\
\hline Long-crested Eagle & Agricultural & 94 & MCDS & Half normal & & 124 & 11.56 & $(8.37-15.96)$ \\
\hline \multirow[t]{2}{*}{ Lophaetus occipitalis } & Savanna & 151 & MCDS & Half normal & & 164 & 8.42 & $(6.03-11.76)$ \\
\hline & Pastoral & 92 & MCDS & Half normal & & 135 & 10.15 & $(7.23-14.23)$ \\
\hline Martial Eagle & Savanna & 35 & MCDS & Half normal & & 189 & 1.70 & $(1.06-2.71)$ \\
\hline \multicolumn{9}{|l|}{ Polemaetus bellicosus } \\
\hline Bateleur & Savanna & 415 & MCDS & Half normal & Cos. 2 & 197 & 19.29 & $(15.27-24.35)$ \\
\hline Terathopius ecaudatus & Pastoral & 33 & MCDS & Half normal & Cos. 2 & 215 & 3.28 & $(1.48-7.24)$ \\
\hline Common Kestrel & Savanna & 15 & MCDS & Half normal & & 302 & 0.45 & $(0.17-1.22)$ \\
\hline \multicolumn{9}{|l|}{ Falco tinnunculus } \\
\hline Grey Kestrel & Agricultural & 29 & MCDS & Half normal & & 107 & 4.24 & $(2.39-7.51)$ \\
\hline \multirow[t]{2}{*}{ F. ardosiaceus } & Savanna & 106 & MCDS & Half normal & & 113 & 8.54 & $(5.82-12.52)$ \\
\hline & Pastoral & 23 & MCDS & Half normal & & 73 & 6.69 & $(3.60-12.44)$ \\
\hline Red-necked Falcon & Savanna & 20 & MCDS & Half normal & & 152 & 1.19 & $(0.56-2.54)$ \\
\hline \multicolumn{9}{|l|}{ F. ruficollis } \\
\hline Montagu's Harrier & Savanna & 34 & MCDS & Half normal & & 147 & 2.11 & $(1.14-3.91)$ \\
\hline Circus pygargus & Pastoral & 18 & MCDS & Half normal & & 206 & 1.87 & $(0.75-4.65)$ \\
\hline Pallid Harrier & Savanna & 19 & MCDS & Half normal & & 155 & 1.12 & $(0.50-2.49)$ \\
\hline C. macrourus & Pastoral & 9 & MCDS & Half normal & & 334 & 0.58 & $(0.20-1.66)$ \\
\hline Western Marsh-harrier & Savanna & 24 & MCDS & Half normal & & 216 & 1.02 & $(0.58-1.76)$ \\
\hline \multicolumn{9}{|l|}{ C. aeruginosus } \\
\hline Shikra & Agricultural & 22 & CDS & Uniform & Cos. 1 & 108 & 3.19 & $(1.64-6.21)$ \\
\hline \multirow[t]{2}{*}{ Accipiter badius } & Savanna & 19 & CDS & Uniform & Cos. 1 & 127 & 1.37 & $(0.67-2.80)$ \\
\hline & Pastoral & 20 & CDS & Uniform & Cos. 1 & 103 & 4.15 & $(2.42-7.09)$ \\
\hline
\end{tabular}




\begin{tabular}{|c|c|c|c|c|c|c|c|c|}
\hline Species & Land use ${ }^{1}$ & $n^{2}$ & Model $^{3}$ & $\begin{array}{l}\text { Detection } \\
\text { function }\end{array}$ & Adjustments $^{4}$ & ESW $^{5}$ & Density & CLs \\
\hline Grasshopper Buzzard & Agricultural & 8 & MCDS & Half normal & & 163 & 0.76 & $(0.23-2.50)$ \\
\hline \multirow[t]{2}{*}{ Butastur rufipennis } & Savanna & 852 & MCDS & Half normal & & 136 & 57.10 & $(41.73-78.12)$ \\
\hline & Pastoral & 14 & MCDS & Half normal & & 171 & 1.75 & $(0.73-4.18)$ \\
\hline Eurasian Buzzard & Savanna & 26 & MCDS & Half normal & & 137 & 1.74 & $(0.95-3.17)$ \\
\hline \multicolumn{9}{|l|}{ Buteo buteo } \\
\hline Lizard Buzzard & Agricultural & 50 & CDS & Uniform & S. poly. 2 & 88 & 8.88 & $(5.58-14.20)$ \\
\hline \multirow[t]{2}{*}{ Kaupifalco monogrammicus } & Savanna & 29 & CDS & Uniform & S. poly. 2 & 92 & 2.88 & $(1.72-4.82)$ \\
\hline & Pastoral & 27 & CDS & Uniform & S. poly. 2 & 121 & 4.75 & $(2.72-8.27)$ \\
\hline Dark Chanting-goshawk & Agricultural & 24 & MCDS & Half normal & & 239 & 1.57 & $(0.64-3.87)$ \\
\hline \multirow[t]{2}{*}{ Melierax metabates } & Savanna & 50 & MCDS & Half normal & & 143 & 3.19 & $(2.09-4.87)$ \\
\hline & Pastoral & 49 & MCDS & Half normal & & 172 & 6.09 & $(3.03-12.24)$ \\
\hline European Honey-buzzard & Savanna & 126 & MCDS & Half normal & & 150 & 7.66 & $(5.12-11.44)$ \\
\hline Pernis apivorus & Pastoral & 25 & MCDS & Half normal & & 155 & 3.25 & $(1.58-7.54)$ \\
\hline African Harrier-hawk & Agricultural & 13 & MCDS & Half normal & & 210 & 0.97 & $(0.41-2.28)$ \\
\hline Polyboroides typus & Savanna & 35 & MCDS & Half normal & & 159 & 2.01 & $(1.24-3.26)$ \\
\hline Black-winged Kite & Agricultural & 35 & MCDS & Half normal & & 92 & 5.92 & $(3.28-10.68)$ \\
\hline \multirow[t]{2}{*}{ Elanus caeruleus } & Savanna & 26 & MCDS & Half normal & & 80 & 2.98 & $(1.34-6.61)$ \\
\hline & Pastoral & 61 & MCDS & Half normal & & 160 & 8.16 & $(3.97-16.76)$ \\
\hline Black Kite & Agricultural & 1233 & MCDS & Half normal & & 149 & 129.45 & (91.12-183.70) \\
\hline \multirow[t]{2}{*}{ Milvus migrans } & Savanna & 477 & MCDS & Half normal & Cos. 2 & 179 & 24.31 & $(16.65-35.50)$ \\
\hline & Pastoral & 518 & MCDS & Half normal & & 171 & 64.60 & (53.31-78.29) \\
\hline Osprey & Savanna & 15 & MCDS & Half normal & & 302 & 0.45 & $(0.20-1.03)$ \\
\hline \multicolumn{9}{|l|}{ Pandion haliaetus } \\
\hline Palm-nut Vulture & Savanna & 72 & CDS & Uniform & S. poly. 2 & 96 & 6.86 & $(4.19-11.23)$ \\
\hline \multicolumn{9}{|l|}{ Gypohierax angolensis } \\
\hline White-backed Vulture & Savanna & 445 & MCDS & Half normal & & 271 & 15.04 & $(10.12-22.33)$ \\
\hline \multicolumn{9}{|l|}{ Gyps africanus } \\
\hline Gyps spp. & Savanna & 585 & MCDS & Half normal & & 271 & 19.74 & (13.29-29.33) \\
\hline Rüppell's Vulture & Savanna & 139 & MCDS & Half normal & & 271 & 4.71 & $(3.17-6.99)$ \\
\hline \multicolumn{9}{|l|}{ G. rueppelli } \\
\hline Hooded Vulture & Agricultural & 76 & CDS & Half normal & & 112 & 10.59 & $(4.91-22.81)$ \\
\hline \multirow[t]{2}{*}{ Necrosyrtes monachus } & Savanna & 25 & CDS & Uniform & & 500 & 0.46 & $(0.17-1.20)$ \\
\hline & Pastoral & 32 & CDS & Half normal & & 116 & 5.86 & $(2.54-13.55)$ \\
\hline Lappet-faced Vulture & Savanna & 48 & CDS & Half normal & & 200 & 2.19 & $(1.21-3.94)$ \\
\hline \multicolumn{9}{|l|}{ Torgos tracheliotos } \\
\hline White-headed Vulture & Savanna & 26 & MCDS & Half normal & & 227 & 1.05 & $(0.56-1.96)$ \\
\hline Trigonoceps occipitalis & & & & & & & & \\
\hline
\end{tabular}

1 Land use types: savanna transects followed unpaved tracks through open- or wooded grassland within PAs; pastoral transects were on public roads through vegetation that was often superficially similar to that of savanna, but lay outside of PAs; agricultural transects also followed public roads, but through land supporting crops. See Methods for further details

6182 Number of encounters recorded in this land use type

3 Model type. CDS: Conventional Distance Sampling. MCDS: Multiple Covariate Distance Sampling

$620{ }_{4}$ Adjustments: Cosine, Simple Polynomial

622

5 Effective strip width $(\mathrm{m})$ 
Table 2: Raptor species recorded only or much more frequently in protected savanna than in pastoral or agricultural land. The combined number of individuals present in conservation areas (CAs) has been estimated from the species' population density in savanna, and the total area of savanna within the CA network

628

Species Dependency score ${ }^{1}$ Global threat status $^{2} \quad$ Migratory status $^{3} \quad$ Individuals in CA Confidence limits
network

\begin{tabular}{|c|c|c|c|c|c|}
\hline African Hawk-eagle & 1 & Ic & $\mathrm{R}$ & 65 & $(35-121)$ \\
\hline Black-chested Snake-eagle & 1 & Ic & $\mathrm{R}$ & 238 & $(141-401)$ \\
\hline Short-toed Snake-eagle & 1 & IC & PM & 125 & $(55-278)$ \\
\hline Martial Eagle & 1 & VU & $\mathrm{R}$ & 379 & $(237-604)$ \\
\hline Bateleur & 2 & $\mathrm{nt}$ & $\mathrm{R}$ & 4302 & (3 406-5 433) \\
\hline Common Kestrel & 1 & Ic & RPM & 101 & $(37-272)$ \\
\hline Red-necked Falcon & 1 & Ic & $\mathrm{R}$ & 267 & $(126-565)$ \\
\hline Western Marsh-harrier & 1 & IC & PM & 227 & $(130-393)$ \\
\hline Grasshopper Buzzard & 2 & Ic & AM & 12737 & (9 308-17 427) \\
\hline Eurasian Buzzard & 1 & Ic & PM & 388 & $(212-708)$ \\
\hline Osprey & 1 & Ic & PM & 101 & $(44-230)$ \\
\hline Palm-nut Vulture & 1 & Ic & $\mathrm{R}$ & 1530 & $(934-2505)$ \\
\hline White-backed Vulture & 1 & $\mathrm{CR}$ & $\mathrm{R}$ & 3354 & (2 257-4 982) \\
\hline Rüppell's Vulture & 1 & $\mathrm{CR}$ & $\mathrm{R}$ & 1050 & $(707-1560)$ \\
\hline Lappet-faced Vulture & 1 & EN & $\mathrm{R}$ & 489 & $(271-880)$ \\
\hline White-headed Vulture & 1 & $\mathrm{CR}$ & $\mathrm{R}$ & 233 & $(124-436)$ \\
\hline
\end{tabular}

6301 Dependency on protected savanna was scored as: 1. species only recorded in savanna, or encounters in pastoral and agricultural land too few to support density estimation in these land use types; 2 . highest density attained in pastoral or agricultural land was $\leq 25 \%$ of density in savanna. Species whose density in pastoral or agricultural land was $>25 \%$ of their density in savanna have been excluded

2 Global threat status: Ic least concern; nt near threatened; VU Vulnerable; EN Endangered; CR Critically Endangered. Source: BirdLife International (2018)

3 Migratory status in Uganda: AM Afrotropical migrant; R resident; RPM both resident individuals and Palearctic migrants present; PM Palearctic migrant 
Table 3: Estimates of the number of adult pairs present in Uganda's conservation areas, for resident raptor species highly dependent on savanna habitats

\begin{tabular}{|c|c|c|c|c|c|c|c|c|c|c|}
\hline \multirow[b]{2}{*}{ Species } & \multirow[b]{2}{*}{$\begin{array}{r}\text { Proportion } \\
\text { assumed } \\
\text { adult } 1\end{array}$} & \multirow[b]{2}{*}{ Source $^{2}$} & \multirow[b]{2}{*}{$\begin{array}{r}\text { Area pair }{ }^{-1} \\
\left(\mathrm{~km}^{2}\right)\end{array}$} & \multicolumn{2}{|c|}{$\begin{array}{l}\text { Total pairs, } \\
\text { assuming: }\end{array}$} & \multirow[b]{2}{*}{$\begin{array}{r}\text { Occupied } \\
\mathrm{CAs}^{4}\end{array}$} & \multicolumn{3}{|c|}{$\begin{array}{c}\text { Number of CAs likely to } \\
\text { support }\end{array}$} & \multirow[b]{2}{*}{$\begin{array}{r}\% \text { pairs in } \\
\text { five largest } \\
\mathrm{CAs}^{4}\end{array}$} \\
\hline & & & & $\begin{array}{r}75 \% \\
\text { adults } \\
\text { paired }\end{array}$ & $\begin{array}{l}100 \% \\
\text { adults } \\
\text { paired }\end{array}$ & & $\begin{array}{r}<5 \\
\text { pairs }\end{array}$ & $\begin{array}{l}5-20 \\
\text { pairs }\end{array}$ & $\begin{array}{r}>20 \\
\text { pairs }\end{array}$ & \\
\hline African Hawk-eagle & 0.65 & 1 & [3] & 3 & 5 & 2 & 2 & 0 & 0 & $100 \%$ \\
\hline Black-chested Snake-eagle & 0.65 & 1 & $288-384$ & 30 & 42 & 5 & 3 & 2 & 0 & $98-100 \%$ \\
\hline Martial Eagle & 0.65 & 1 & $181-241$ & 53 & 75 & 7 & 2 & 5 & 0 & $93-96 \%$ \\
\hline Bateleur & 0.65 & 2,3 & $16-21$ & 862 & 1,191 & 54 & 39 & 8 & 7 & $73-75 \%$ \\
\hline Red-necked Falcon & 0.65 & 1 & $257-342$ & 34 & 49 & 6 & 3 & 2 & 0 & $96-97 \%$ \\
\hline Palm-nut Vulture & 0.55 & 2,4 & $53-71$ & 222 & 307 & 15 & 8 & 2 & 5 & $84-86 \%$ \\
\hline White-backed Vulture & 0.80 & 2,5 & $17-22$ & 828 & 1,145 & 54 & 39 & 8 & 7 & $73-76 \%$ \\
\hline Rüppell's Vulture & 0.80 & 6 & $53-71$ & 222 & 307 & 15 & 8 & 2 & 5 & $84-86 \%$ \\
\hline Lappet-faced Vulture & 0.66 & 7 & $138-184$ & 74 & 105 & 9 & 4 & 4 & 1 & $91-93 \%$ \\
\hline White-headed Vulture & 0.54 & 8 & $354-472$ & 22 & 32 & 5 & 3 & 2 & 0 & $100 \%$ \\
\hline
\end{tabular}

1 The proportion of individuals assumed to be adult, and hence of breeding age

6422 Sources used for estimating the proportion of adult birds in the population. 1. Mean of estimates for five species for which published sources were available; 2. Brown et al. (1997); 3. Watson (1990a); 4. Kemp and Kirwan (2018); 5. Anderson (2000), Murn et al. (2002), Monadjem et al. (2012). 6. Assumed to be as for W-b Vulture;

$644 \quad$ 7. Mundy et al. (1992); 8. Murn et al. (2016)

3 Density extremely low; estimated area required pair ${ }^{-1}$ likely to be misleading

${ }^{4}$ Assuming $75 \%$ of adults are in pairs 
Table 4: The influence of land use and tree cover on: the likelihood of a species being encountered on a given transect (Binomial models); and the number of individuals recorded (Poisson models). The latter were restricted to surveys of transects in which at least one individual of the target species was seen. For effect sizes, see Supplementary Table S2. Globally threatened and near-threatened species are shown in bold and bold-italics, respectively

\begin{tabular}{|c|c|c|c|c|c|}
\hline \multirow[b]{2}{*}{$\begin{array}{l}\text { Explanatory } \\
\text { variable }\end{array}$} & \multirow[b]{2}{*}{ Model type } & \multicolumn{4}{|c|}{ Species' presence or abundance positively associated with: } \\
\hline & & Savanna & Savanna-Pastoral & Pastoral & Pastoral-Agricultural \\
\hline \multirow[t]{10}{*}{ Land use } & $\begin{array}{l}\text { Binomial } \\
\text { (presence/ }\end{array}$ & $\begin{array}{l}\text { Steppe Eagle** } \\
\text { African Fish-eagle }\end{array}$ & $\begin{array}{l}\text { Brown Snake-eagle* } \\
\text { Montagu's Harrier* }\end{array}$ & $\begin{array}{l}\text { Tawny Eagle+ } \\
\text { W. Banded Snake-eagle+ }\end{array}$ & $\begin{array}{l}\text { Wahlberg's Eagle* } \\
\text { Long-crested Eagle** }\end{array}$ \\
\hline & absence) & Martial Eagle $\mathrm{e}^{\star * *}$ & Eurasian Buzzard+ & Dark Chanting-goshawk+ & Shikra** \\
\hline & & Bateleur*** & & & Black-winged Kite+ \\
\hline & & Red-necked Falcon* & & & Black Kite ${ }^{\star * *}$ \\
\hline & & Western Marsh-harrier+ & & & Hooded Vulture ${ }^{\star *}$ \\
\hline & & Grasshopper Buzzard** & & & \\
\hline & & European Honey-buzzard** & & & \\
\hline & & White-backed Vulture ${ }^{\star * *}$ & & & \\
\hline & & Rüppell's Vulture* & & & \\
\hline & & White-headed Vulture ${ }^{* *}$ & & & \\
\hline \multirow[t]{4}{*}{ Land use } & Poisson & Steppe Eagle $e^{* *}$ & - & White-headed Vulture** & Hooded Vulture ${ }^{\star \star}$ \\
\hline & (abundance) & Tawny Eagle* & & & \\
\hline & & Bateleur+ & & & \\
\hline & & Grey Kestrel ${ }^{* * *}$ & & & \\
\hline Feature & Model type & Open grassland-light tree cov & & Heavy tree cover-closed c & opy \\
\hline \multirow[t]{5}{*}{ Tree cover } & Binomial & Red-necked Falcon+ & & Wahlberg's Eagle** & \\
\hline & (presence/ & Montagu's Harrier* & & Bateleur* & \\
\hline & absence) & Western Marsh-harrier** & & & \\
\hline & & Black-winged Kite+ & & & \\
\hline & & Rüppell's Vulture* & & & \\
\hline \multirow[t]{4}{*}{ Tree cover } & Poisson & Steppe Eagle ${ }^{* * *}$ & & Rüppell's Vulture** & \\
\hline & (abundance) & Grey Kestrel $^{\star}$ & & Hooded Vulture ${ }^{\star *}$ & \\
\hline & & Grasshopper Buzzard** & & & \\
\hline & & European Honey-buzzard* & & & \\
\hline
\end{tabular}

${ }^{* * *} p<0.001 ;{ }^{* *} p<0.01 ;{ }^{*} p<0.05 ;+p<0.10$ 


\section{Figure legends}

Figure 1: Routes surveyed during annual road counts, 2008-2015. Black lines indicate public roads surveyed through farmland, and unpaved tracks surveyed within four National Parks. Place names are as follows: ET Entebbe; KP Kampala; KVNP Kidepo Valley NP; LMNP Lake Mburo NP; MBNP Mbarara NP; MFNP Murchison Falls NP; MR Moroto; QENP Queen Elizabeth NP; SR Soroti

Figure 2: The effects of habitat fragmentation on population estimates for 10 resident, savanna-dependent species. Population sizes were estimated in two ways: A. by multiplying the combined area of protected savanna in all conservation areas (CAs) by the species' density in that habitat; B. by multiplying the area of protected savanna in each CA by the species' density, but excluding CAs with too little savanna to support at least the species in question. Population estimates were $41 \%$ lower (median; quartiles: $28-48 \%$ ) when sites with insufficient savanna were excluded $(B)$, than when all protected savanna was treated as a single block $(A)$ 


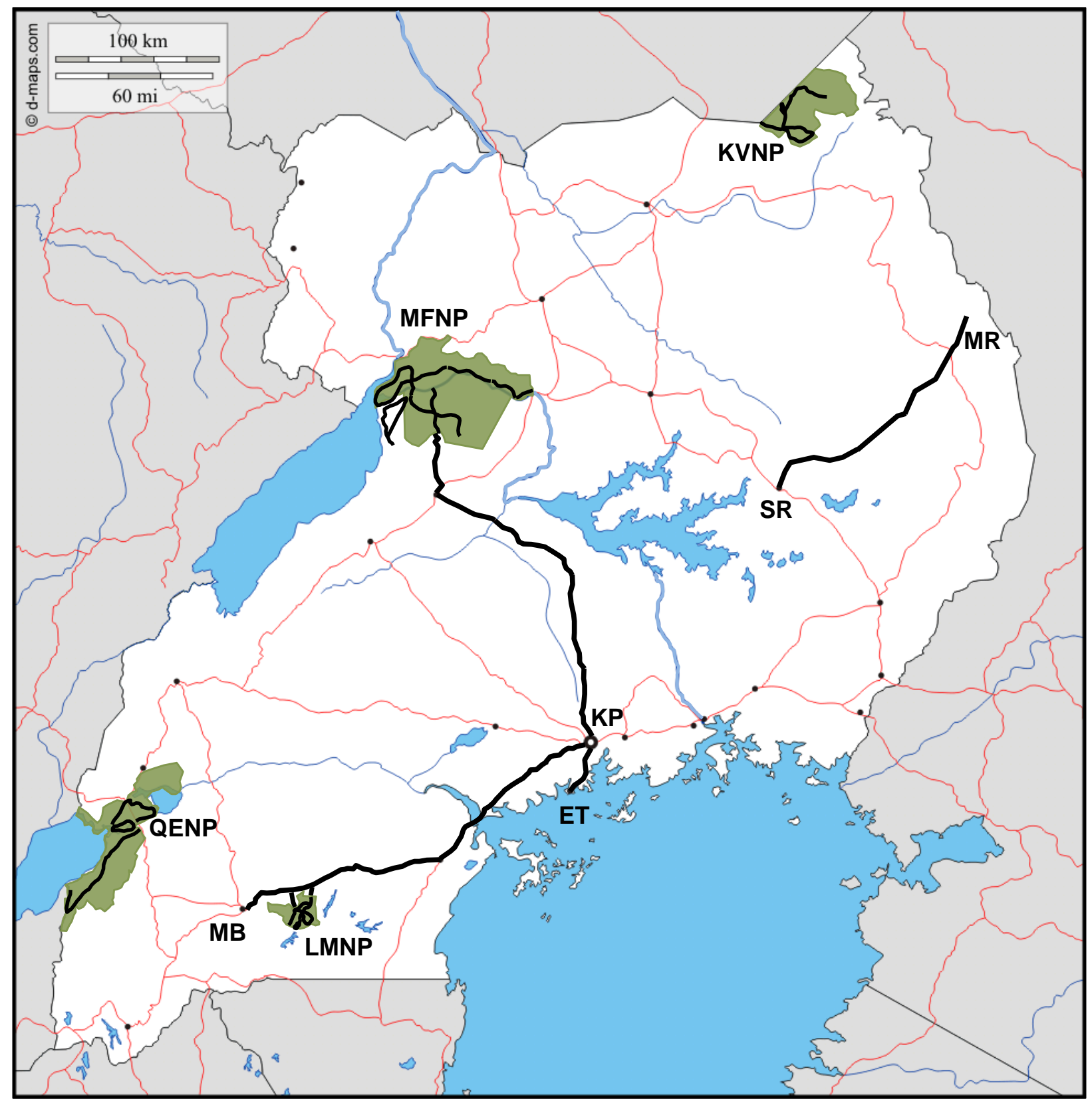


Fig. 2

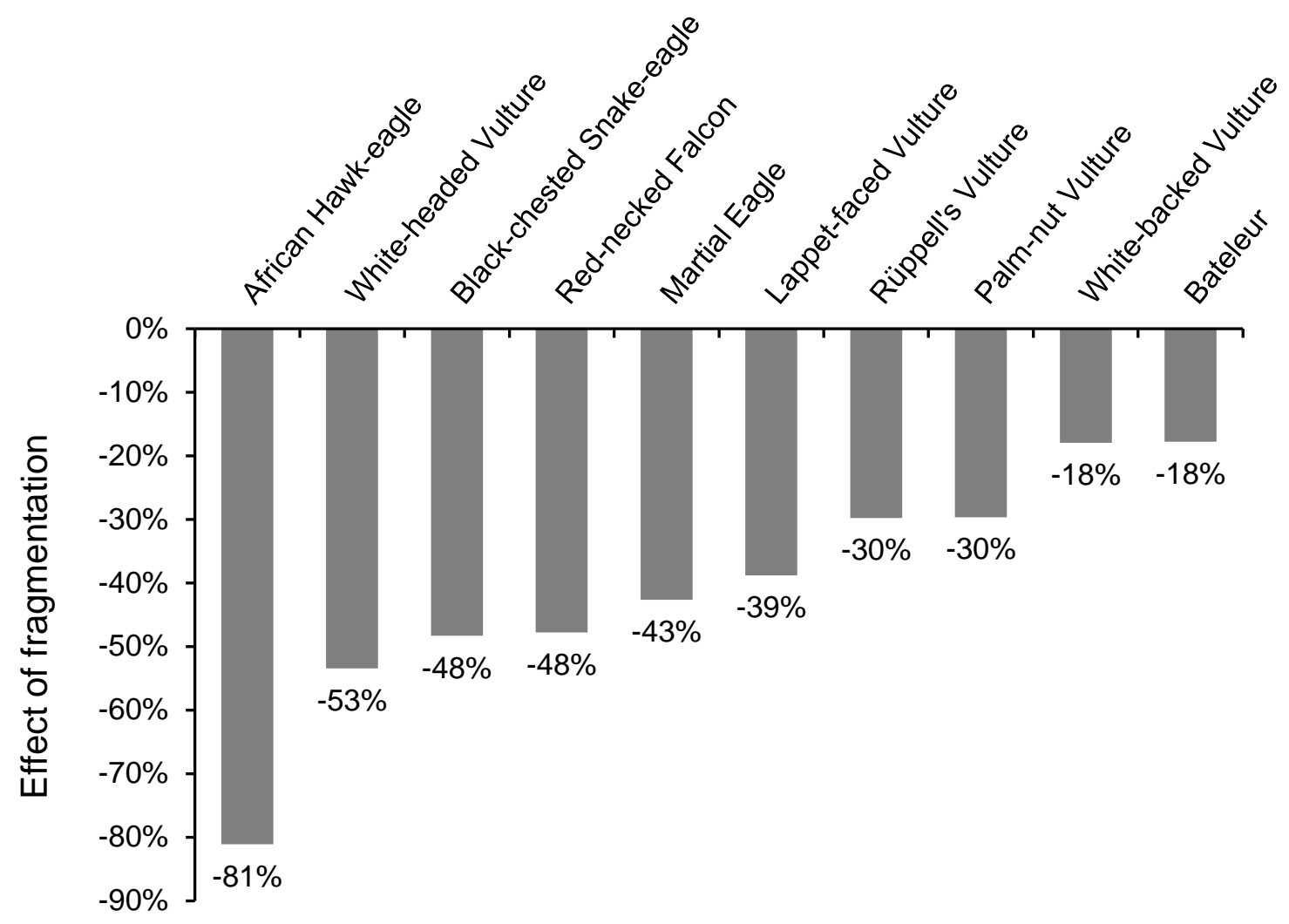

